\title{
大豆およびその加工品の栄養価に関する研究 Studies on the Nutritive Value of Soybean and Its Products
}

(昭和 35 年 9 月 14 日受理)

$\begin{array}{ccc}\text { 林 } & \text { 筧 } & \text { 有 山 } \begin{array}{c}\text { 恒 } \\ \text { (Yutaka Hayashi) }\end{array}\end{array}$

The differences of the nutritive value were presented in comparison with the rate of gain, serum protein, liver-fat, -phospholipid and -glycogen of weanling rats fed with various types of soybeans and its products as their sole source of protein in vivo.

Autoclaved soybean meal produced the best growth, and Kinako meal, boiled soybean meal, Tofu meal and Natto meal followed. The addition of methionine to the boiled soybean, Kinako and Tofu meal resulted in some growth improvement, and also the addi tion of autoclaved soybean to the Natto meal showed a good effect.

The levels of serum protein, liver-fat, -phosphlipid and -glycogen of animals showed no remarkable difference in each group.

楮言

著者らは先に大豆蛋白質の加熱による栄養価の差異を みる目的で in vitroの人工消化試呀をおこなった結果， $110^{\circ} \mathrm{C}$ の加圧鉒加熱加最も消化度が高く, ついで 130 C の加圧釜加熱，水募沸の順となり，乾熱は対照の生より むしろ悪く，特に $150^{\circ} \mathrm{C}$ の乾熱は最も低い值を示すこ と，そしてこの傾向は大豆の栄養制限 アミ/酸である methionine, cystine および lysine の遊離度にもみら れることを報告〉したが，本報では in vivoの試験上し て大豆およびその加工品を唯一の蛋白質給源とする食伹 でシロネズミを飼育し，その栄美価の差異を体重增加，

肝满重量, 血清蛋白質, 肝䑏脂肪, 肝炡燐脂質および肝 婼グリコーゲン量など卒測定することにより比較検定し たのでここに報告する，

\section{実 験 方 法}

\section{（1）実験動物および飼育方法}

実験動物としてWistar 系の雄シロネズミ, 体重 $50 \mathrm{~g}$ 前後のものを用いた。各群 ( 1 群 5 匹) に同腹のものを できるだけ均等に配分し，1匹ずつ铜育力ゴに分離，完 全飼料を 7 日間与えた後試験食聑にきりかえた。試験食 眲組成は第 1 表に示すごとく、、ずれの試験群も蛋白質 が 10 \%となるようにした。食慨はこれとほぼ同量の水 を加えてねり，呲粉が糊化する程度に軽く加熱した。飼 育期間は 40 日とし，25 日目からは水募沸大豆, 垩粉お よび豆腐の各群には DL-methionine $0.3 \%$ ·を添加し， 納豆群は蛋白倎の 2 割を加圧釜加熱大豆でおきかえた。 食䁒および水は自由揑取とし，試験食餌を与えはしめて
から体重は隔日測定した，

第 1 表 试硔食䬱組成（g/100g）

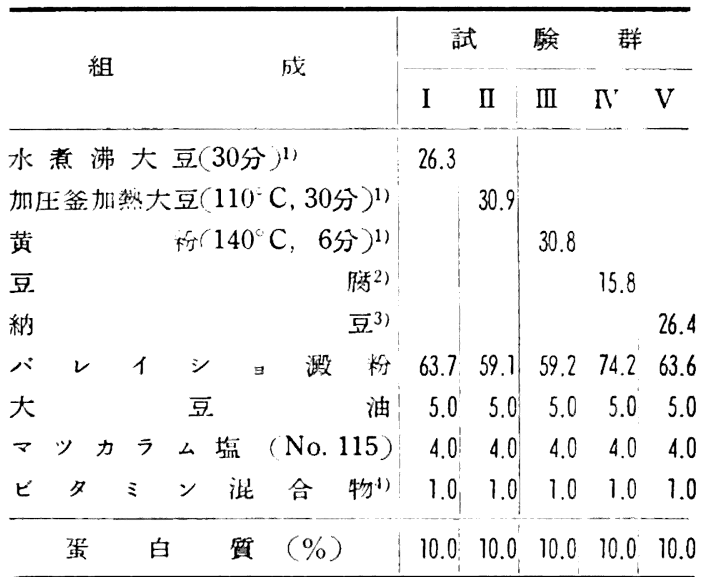

1) 中共大豆; 加駑处理後送風乾燥して粉末にした के。

2) 乾燥豆腐; 倍州松尾旭松東豆腐 $\mathrm{K} \mathrm{K}$ 製品。

3) 仙台方宫城野納豆K K 製品。

4) 食餌 $100 \mathrm{~g}$ 中の $\mathrm{mg}$; サイアミン 1.0, リホフ ヒン 1.0 , ピリドキシン 2.0 , パントテン酸カル シウム 3.0 , ナイアシン 2.5 ,コリン $100.0,1$, シトール 10.0 , ビオチン 0.04 , 彗酸 0.2 。 各動物に肝油を 1 週あたり 2 滴与えた。

(2) 血清蛋白質の测定

血清の蛋白質はシロネズミを飼育後 40 日目に斬首採 血し,フイブリンを除去, 血清を遠心分離して蛋白計に より測定した。

(3) 朋臟脂肪おうひび燐脂質の定量

肝脕を蒸気浴中で完全に乾嬠後粉末にしたものを熱ア ルコールで抽出, そのエーテル可溶性部分を総脂肪量上 
した。燐脂質は Best ら²)の方法により定最した。

(4) 肝臓グリコーゲンの定量

肝臟グリコーゲンはanthrone 試薬を用いるSeifter らろ)の方法により測定した。すなわち，肝歲をトーシ ョンバランスこ和证し， $30 \% \mathrm{KOH}$ で水解したのち $95 \%$ アルコール各加えてグリコーゲンを沈港させ, 遠

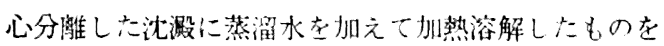
検液上し， anthrone 武薬点加えて発色させたのち比 色定量した。

\section{実験結果とその考察}

試験食触によるシロネズミの体重曲線主第 1 以に，

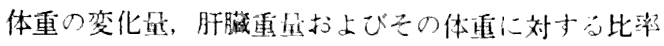

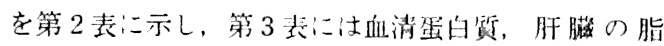

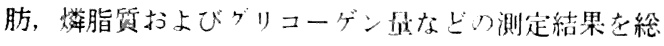
括して示しに。

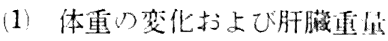

体重増加显は24 日目までの変化をみると加压釜加 熱大豆群ボ最もよく 1 週間へ增加地は $20.3 \mathrm{~g}$ であり， 以下黄粉群 $15.2 \mathrm{~g}$ ，水惹沸大豆群 $13.2 \mathrm{~g}$, 豆腐群 $12.1 \mathrm{~g}$

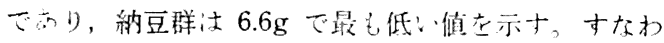
ち，体重增加释過加的万上加压釜加熱大豆が最も すぐれているこレがわかる、一方，水煮沸大豆，黄粉 および豆腐の各群に DL - methionine $0.3 \%$ 在添加す

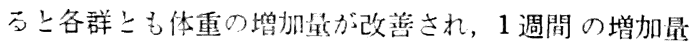
は 22.3 22.7g でこれらの各群間に有意差がなくなり， また納豆群も加压釜加熱大豆を添加十るここて作重增加

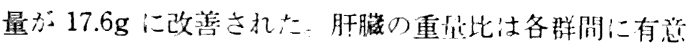
の差㒛はら机ない。

(2) 血清蛋白質, 肝臟の脂肪，燐脂質およびグリコー ゲン星

測定の結果は第 3 表に示しにことく，各群閒に顕著な
第1四之ロネズミの曲線

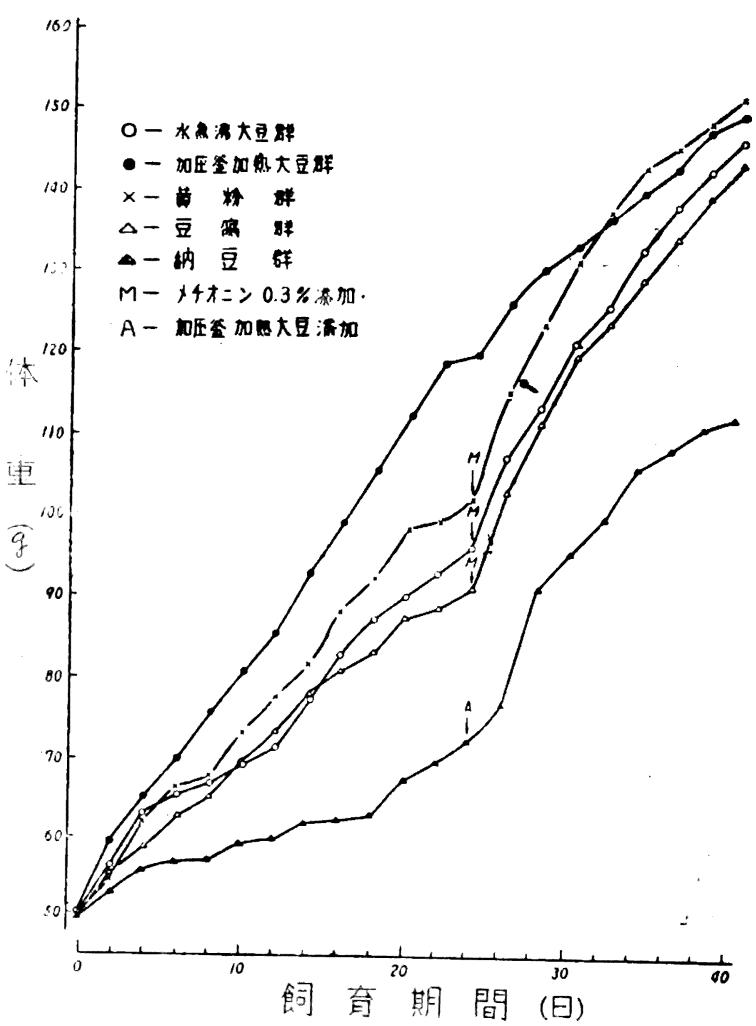

蒫が認められず，最も成坟のよい加圧釜加熱大豆群とほ ぽ同じ傾向を示す。これは methionine や打圧釜加熱大 豆を添加したため，加圧釜加熱火豆群に近い条件になっ たため上考えられる，肝炡脂肪量が割合に高い値を示す のは，食佃の蛋白質量が低いことならびに methionine

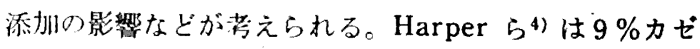
イン食への methionine の添加が脂肪肝をおこすことを 報告しているが, いわゆる lipotropic substance とし

第 2 表 シロネズミの体重打よび肝歲重量

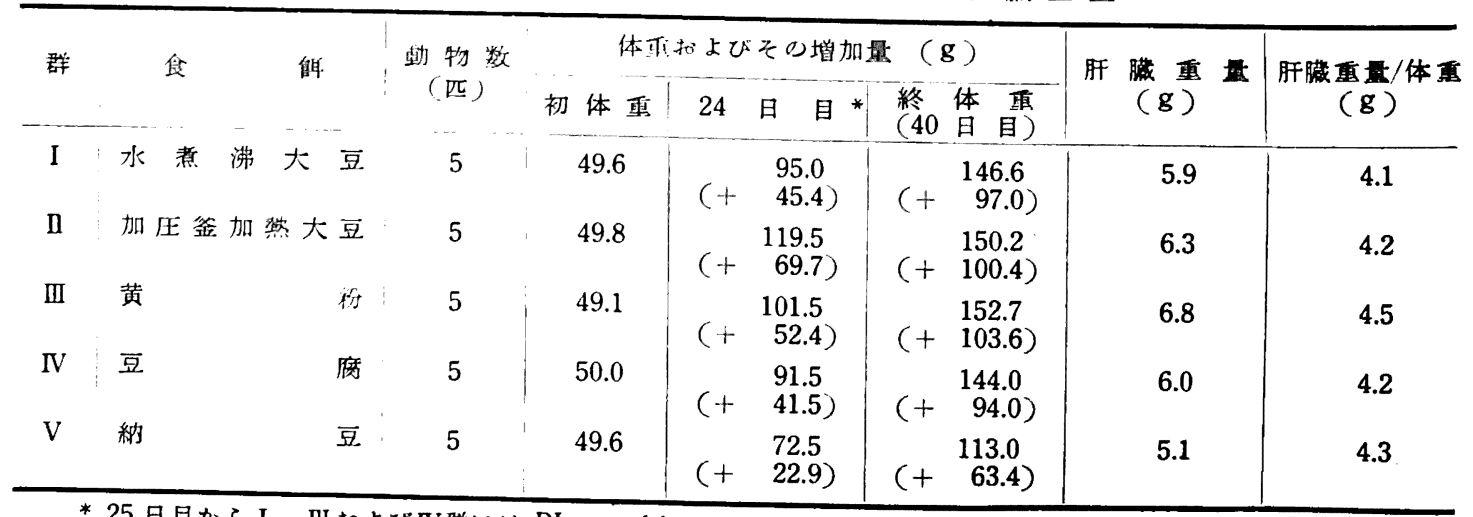

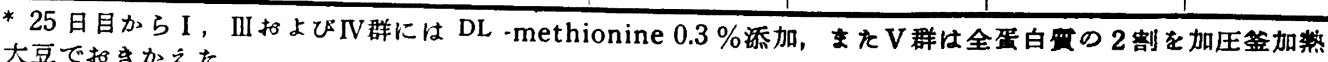
大豆で扣さかえた。 
第13巻 第 5 号

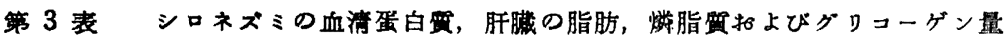

\begin{tabular}{|c|c|c|c|c|c|c|c|}
\hline \multirow{2}{*}{ 群 } & \multirow{2}{*}{ 食 } & \multirow{2}{*}{$\begin{array}{c}\text { 動物数 } \\
\text { (匹匹) }\end{array}$} & \multirow{2}{*}{ 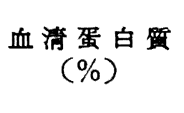 } & \multicolumn{2}{|c|}{ 肝䑏 脂 肪 (\%) } & \multirow{2}{*}{$\begin{array}{c}\text { 肝微燐 脂 貎 } \\
(\%)\end{array}$} & \multirow{2}{*}{$\begin{array}{c}\text { 肝 } \\
\text { グロコーゲン } \\
\left(\begin{array}{l}\text { 藏 } \\
0\end{array}\right) .\end{array}$} \\
\hline & & & & 乾物 最 & 生 鮮 物 最 & & \\
\hline I & 水意沸大豆 & 5 & $5.4 \pm 0.1^{*}$ & $22.0 \pm 0.7$ & $6.6 \pm 0.2$ & $3.2 \pm 0.1$ & $2.0 \pm 0.2$ \\
\hline II & 加珐金加慗大豆 & 5 & $5.1 \pm 0.1$ & $22.7 \pm 0.8$ & $6.0 \pm 0.3$ & $3.1 \pm 0.2$ & $2.3 \pm 0.1$ \\
\hline III & 黄 & 5 & $5.3 \pm 0.2$ & $22.6 \pm 1.7$ & $5.8 \pm 0.5$ & $3.0 \pm 0.1$ & $2.3 \pm 0.1$ \\
\hline IV & 豆 & 5 & $5.1 \pm 0.1$ & $22.8 \pm 0.2$ & $6.1 \pm 0.4$ & $3.2 \pm 0.1$ & $2.2 \pm 0.2$ \\
\hline $\mathrm{V}$ & 秋 & 5 & $4.9 \pm 0.1$ & $23.8 \pm 0.4$ & $6.8 \pm 0.1$ & $3.0 \pm 0.1$ & $1.8 \pm 0.1$ \\
\hline
\end{tabular}

*標準唉差

ての methionine の働きは,その食慨蛋白睤の量あるい はそのアミノ酸組成によって，全く逆の結果をもたらす 可能性のあることが考えられる。

加圧釜加熱大豆が最も栄養価のよいことはすでに in vitro の消化試験で証明し，また $150^{\circ} \mathrm{C}, 30$ 分の乾熱加 熱のような過熱処理が消化度を低下させることを報告い したが，乾熱加熱でも 5 分くらいの短時間の処理，士な わち黄粉のような加工処理では栄養価が割合によいこと がわかる。

大豆は蛋白兵に富み，そのアミノ酸のバランスも植物 性蛋白質として分析的には悪くないが，実際の栄養価は 加工の如何によって相当に異ってくる。その主な原因は 消化によるアミノ酸の遊離速度やその吸収速度のちがい にあることが前報に引きつずき本報の実験成績からも判 断できるので，大豆の食用にあたっては加工処理が非常 に重要な問題となってくる。

\section{要旨}

(1) 大豆およびその熱加工品を唯一の蛋白質給源よす る食䬣でシロネズミを飼育し，この栄趇価の差異茎比較 した。

（2）加圧釜加熱大豆群が最もよう成長を示し，以下黄
粉，水煮沸大豆，豆腐，約豆の各群の順であった。しか し，黄粉，水煮洲大豆扩上び豆腐门各群に methionine

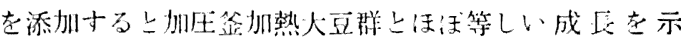
し，また納豆群に玔压釜㖄熱大至の添加で成長が著しく 改善された。

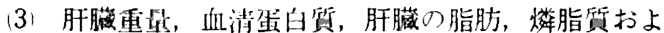
びグリコーゲン量な上には各群間に有意差が認められな かったが，これは methionineや加压釜加熱大豆の添加 のためと考えられる。

(4)大豆の栄養洒の差哄消消化によるアミノ酸门遊離 速度のちがいによるので，大豆の食用に際してはこの加 工処理上いうこもも見落してはならない重要な問題であ 门，大豆りもつ栄虫素在損失なく最有効に利用しなけ れ洨ならない。

文献

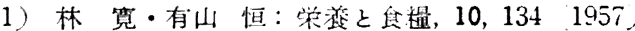

2) Best, C. H. et al. : Biochem. J., 40, 368 1946)

3) Seifter, S. et al. : Arch. Biochem. Biophys., 25, $191(1950$

4) Harper, A. E. et al. : Proc. Soc. Exptl. Biol. Med., 87, 544 (1954)

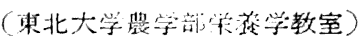

